\title{
WOMEN PARTICIPATION AS AGENT OF CITIZEN'S DIPLOMACY THROUGH SOLO INTERNATIONAL PERFORMING ART (SIRPA)
}

\author{
Setyasih Harini, ${ }^{1}$ Tracy Wright Webster ${ }^{2}$ \\ Slamet Riyadi University, University of Western Australia
}

\begin{abstract}
Women affiliated with Semarak Candrakirana Art Studio have been carrying out a set of artistic performances, in particular, dance. This art studio was established and developed by women art activists to preserve national culture. One of the activities organised by Semarak Candrakirana to preserve national culture is, among others, the organization of international events. The objective of this research is to explain the women's participation as agents of citizen diplomacy by introducing Indonesian culture through Solo International Performing Art (SIPA). To analyze the case, the theory of citizen diplomacy and post-feminism is used. The findings showed that the women of Semarak Candrakirana Art Center promote Javanese culture through their international performances. These activities fall into the category of citizens diplomacy, supporting the Indonesian government's diplomatic efforts to strengthen relations with other countries.
\end{abstract}

Keywords: Women, culture, international event, citizen diplomacy

Título en Castellano: Participación de las mujeres como agentes de la diplomacia ciudadana a través de Solo International Performing Art (SIPA)

\section{Resumen:}

Las representaciónes artísticas, particularmente la danza, se han venido realizando por mujeres afiliadas al Estudio de Arte Semarak Candrakirana. Este estudio de arte fue establecido y desarrollado por mujeres activistas que querían preservar la cultura nacional. Dentro de los intentos realizados por Semarak Candrakirana para preservar la cultura nacional esta, entre otros, organizar eventos internacionales. El objetivo de la investigación es explicar la participación de las mujeres como agentes de la diplomacia ciudadana en la introducción de la cultura indonesia a través de Solo International Performing Art (SIPA). Para analizar el caso, se utiliza la teoría de diplomacia ciudadana y de postfeminismo. El artículo muestra cómo las mujeres del Centro de Arte Semarak Candrakirana promueven la cultura javanesa a través de sus presentaciones internacionales. Se puede considerar estas actividades como representativas de la diplomacia de los ciudadanos apoyando los esfuerzos diplomáticos del gobierno indonesio encaminados a fortalecer las relaciones con otros países.

Palabras Clave: Mujeres, cultura, evento internacional, diplomacia ciudadana

Copyright @ UNISCI, 2019

Las opiniones expresadas en estos artículos son propias de sus autores, y no reflejan necesariamente la opinión de UNISCI. The views expressed in these articles are those of the authors, and do not necessarily

reflect the views of UNISCI.

\footnotetext{
${ }^{1}$ Setyasih Harini is Lecturer of Social and Political faculty, Slamet Riyadi University, Surakarta, Central Java, Indonesia,

E-mail: <setyasih.rini@gmail.com>

${ }^{2}$ Tracy Wright Webster, Ph. D Asian Studies (UWA) is an independent researcher of Indonesia, E-mail: <tracywrightwebster@yahoo.com.au> DOI: http://dx.doi.org/10.31439/UNISCI-87
} 


\section{Introduction}

Diplomacy is a distinctive manifestation of relations established between states. Diplomacy traditionally and formally is an activity mainly conducted by men. ${ }^{3}$ Men have higher negotiating ability level. ${ }^{4}$ On the other hand, women's struggle for obtaining a formal role in the diplomatic process and being a diplomat is still strong and complex in many countries. History records diplomacy activities generally played by men. ${ }^{5}$ The result of previous studies indicates that in building diplomacy activity, women are trusted poorly by the society. Women have an opportunity of entering into diplomacy activity with the development of communication technology. ${ }^{6}$ It is this opportunity that is used by women in Surakarta City to join Semarak Candrakirana Art Studio.

Semarak Candrakirana Art Studio has attempted to perform in foreign countries since its establishment in 1998. This education institution has developed an international network, thereby frequently giving the students the opportunity of performing Archipelago dance in international scope. Alumni, having completed their study, still have relationship with the citizens of other states. Semarak Candrakirana Art Studio has 150 students, most of them, 135, are women. Out of these women, fifteen visit some states actively to introduce Archipelago culture through both classical and modern dance performance. Dance staging by studio members at international level is an important factor contributing to the successful organization of international art performance called Solo International Performing Art (SIPA). This international-scale art event is initiated and sponsored by studio members and art activist community existing in Surakarta. Local Government is so far limited to give permission to the organization, to build, and to support safety protection. The international art performance is held annually in Surakarta City by involving dancers coming from foreign countries. SIPA was held firstly in Surakarta in 2009. To hold SIPA in 2018-2019, foreign dancers contributing to the event came from India, South Korea and other countries.

This research analyzes the role of women as citizen in diplomatic activities through the art of dance at international level. Meanwhile, the objective of this research is to explain the attempts taken by women affiliated with Semarak Candrakirana Art Studio in organizing SIPA 2018-2019. It is important to be presented recalling that year related to the beginning of the radical group soldiers return to their own states. ${ }^{7}$ Indonesia is so far known by international community as the state with a number of its citizens affiliated with the radical group. Art staging becomes an alternative to Indonesians to improve their image and bargaining position because culture has high values acceptable to people with different background. International levelculture through SIPA becomes a means of showing to the public that safety and comfort are still protected by government.

\footnotetext{
${ }^{3}$ Towns, Ann, and Birgitta Niklasson: "Gender, International Status, and Ambassador Appointments", Foreign Policy Analysis Vol. 13, nº 3 (July 2017), pp. 521-540.

${ }^{4}$ Aggestam, Karin, and Annika Bergman-Rosamond: "Swedish Feminist Foreign Policy in the Making: Ethics, Politics, and Gender”, Ethics \& International Affairs Journal, Vol. 30, n 3 (Fall 2016), pp. 323-334.

${ }^{5}$ Costigliola, Frank: "Pamela Churchill, Wartime London, and the Making of the Special Relationship", Diplomatic History Vol 36, no 4 (September 2012), pp. 753-762. See also Dean, Robert: "The Personal and the Political: Gender and Sexuality in Diplomatic History”, Diplomatic History Vol. 36, no 4 (September 2012), pp. $793-767$. Asante, Kwadwo Adusei, et al: "Gender Mainstreaming and Women's Roles In Development Projects: A Research Case Study From Ghana, Feminism", Social Science and Knowledge Advances in Gender Research, Vol. 20 (August 2015), pp. 177-198.

${ }^{6}$ McCarthy, Helen, and James Southern: "Women, Gender and Diplomacy: A Historical Survey" in Cassid Jennifer (ed) (2017): Gender and Diplomacy, London and New York, Routledge, pp.15-31

${ }^{7}$ PBB: 30 ribu Militan ISIS Tinggalkan Irak dan Suriah, 14 Agustus 2018 Tempo.co.id
} 


\section{The Citizens Role as Actors in Citizen Diplomacy}

The state as the main actor in international relations is not marginalized but has been transformed so far. The state as a purposeful actor is balanced with "populism" actor. "Populism" actor refers to the role of citizens to represent the state institution in establishing international relations. ${ }^{8}$ The role of citizens in international relations becomes a new alternative actor at grass-root scale. The new role of citizens is expected to reduce the difficulties resulting from inter-state relations at legal formal level. Such role helps the government's attempt of reducing and resolving inter-state conflict all at once. ${ }^{9}$ The role of citizens in establishing international relations is the manifestation of the public participation related to a community development plan and policy. ${ }^{10}$ In other words, the role of citizens in international relations becomes an alternative strategy to solve problems to accompanying and supporting the diplomatic initiatives taken by government.

Some studies show the presence of two new roles for the citizens as non-state actors in global governance. ${ }^{11}$ These new roles are first of all that citizens, as agents in the international system, increase the international community's understanding of the national identity of a state. This is related to each state's potencialities, including natural resources and culture to support the national political and economic power. This role can be implemented by holding international festivals, conferences and events. Secondly, citizens serve as an accompanying actor complementing the government's role in resolving a conflict. Citizens have the potential to support a conflict resolution attempt taken by the government. The citizen activity in supporting government is conducted informally by means of communicating with the citizens of other states.

The evolving role of citizens is affected by increasing threats and problems that are taking place in interstate relations, unsoluble by governments. Such a role is now known as citizen diplomacy. The role of citizens interacting internationally with the state diplomacy has to be recognized as a right of a state's population and as an obligation of the government given the assitance they provide for implementing the national interest. ${ }^{12}$

Thus, citizen diplomacy is the embodiment of two diplomatic lines (Track -II) not involving governments. The second line of diplomacy tends to be gentler aiming to improve dialogue, kinship, information exchange and joint activity organization. ${ }^{13}$ Citizen diplomacy implies the transfer of information and transnational idea through inter-group and community interaction and the community not in contradiction with the implementation of foreign policy

\footnotetext{
${ }^{8}$ Hadiz VR and Chryssogelos A: Populism in world politics: A comparative cross-regional perspective. International Political Science Review Vol.38 no 4 (2017) pp. 399-411. See also Jewkes, Rachel, et al: "Hegemonic masculinity: combining theory and practice in gender interventions", Culture, Health \& Sexuality Journal, Vol. 17, no ${ }^{\circ} 2$ (2015), pp. 112-127.

${ }^{9}$ Fulda, Andreas: "The Emergence of Citizen Diplomacy in European Union- China Relations: Principles, Pillars, Pioneers, Paradoxes", Diplomacy \& Statecraft, Vol. 30, no 1 (2019), pp. 188-216.

${ }^{10}$ Kumar, Anup \& Holli A. Semetko: "Peace Communication in Cross-border MediaFlows", Journal of Communication, Vol. 68, nº 3 (June 2018), pp. 612-635.

${ }^{11}$ Scoth Gilles \& Smith: “Introduction: Private Diplomacy, Making the Citizen Visible”, New Global Studies, Vol.8, n 1 (March 2014), pp. 1-7. See Lips B. Mirriam A.: "Reconstructing, Attributing and Fixating Citizen Identities in Digital-era Government”, Media, Culture \& Society, Vol. 35, n 1 (January 2013), pp. 61-70. See also Huijgh, Ellen: "Changing Tunes for Public Diplomacy: Exploring the Domestic Dimension", Exchange: The Journal of Public Diplomacy, Vol. 2, no 1 (2013), pp. 62-73.

${ }^{12}$ Odoh, S.I. et al: "Reflections on the Theory and Practice of Citizen Diplomacy in the Conduct of Nigeria's Foreign Policy", Journal Of Humanities And Social Science, Vol. 19, no 10, Ver. VIII, (2014), pp. 09-14. See Ujara, Ese: "Citizen Diplomacy and Nigeria's International Image: The Social Constructivist Explanation", Covenant Journal of Business and Social Sciences, Vol. 6, n 2 (December 2014), pp. 14-30.

${ }^{13}$ Anamika Barua: "Water Diplomacy as an approach to regional cooperation in South Asia: A case from the Brahmaputra Basin”, Journal of Hydrology, Vol.567 (December 2018), pp. 30-40
} 
having shared objective with the government, to realize the national interest. ${ }^{14}$ Thus, citizens in diplomacy activity are considered as objective (essence) and means (agent or instrument) of government.

\section{Post-feminism in Javanese Culture}

The realization of harmony (comfortable and safe life) to Javanese people becomes life principle manifested into care. Harmony principle contains a prohibition from creating conflict with others. Javanese women think that to realize life harmony, the high values should be complied with. Those high values include material/economic/physical, moral/religious/ethical, psychological and social-cultural ones integrated into one value. Those values have spiritual and material orientations, so that no one surpasses another. ${ }^{15}$ High values in Javanese perspective can be said as a part of post-feminism embodiment. Post-feminism in Gill and Scharff's view tries to redefine the concept of feminism adjusted with the present. The concept of feminism no longer focuses on women's body segment as the objectification, but emphasizes on their potency and competency. Women are given an opportunity of making decision, choice, and being accountable for, thereby contributing to the community. ${ }^{16}$ Thus, women, with their ability and capacity, can elicit material and with their mind can implement their religious moral values. In turn, women can be beneficial to the community.

Post-feminism view is called multicultural feminism. ${ }^{17}$ This idea results from the recognition that gender inequality is still organized in political and economical structures affected by local culture. Multicultural feminism is a series of idea and choice representing individual women's freedom related to the improvement of recognition and understanding on culture as collective identity. For that reason, women should be empowered, i.e. be improved in the term of their potency in order to understand better and to be proud of their culture. Aggestam's argument is confirmed by Kriyantono stating that the empowerment of multicultural women is conducted by giving them appropriate access to culture and making them the agent of diplomacy, non-state diplomat. Such diplomat should not only consist of people with the same education background but can also build on local tradition more strongly. ${ }^{18}$ From the elaboration above, it can be seen the correlation between post-feminism and Javanese cultural philosophy related to women empowerment in maintaining culture. Women should not only be the object of culture, but also be entitled to be actor in preserving and promoting national identity.

\footnotetext{
${ }^{14}$ Melissan Jan and Matthew Caesar-Gordon: "Digital diplomacy" and the securing of nationals in a citizencentric world", Global Affairs, Vol. 2, no 3 (October 2016), European International Studies Association, pp. 110. See also Ogbonnaya, Offor, E. et.al.: “A Critical Reflection On The Theory And Practice Of Citizen Diplomacy In Nigeria’s Foreign Policy And External Relations”, South East Journal of Political Science, Vol. 4, n 1 (2018), pp. 56-67.

${ }^{15}$ Asmarani, Ratna: "Perempuan Dalam Perspektif Kebudayaan”, Sabda, Vol. 12, no 1 (2017), pp 7-16.

${ }^{16}$ Gill, Rosalind and Christina Scharff. (2011): New Femininities: Postfeminism, Neoliberalism and Subjectivity. Hampshire and New York, Palgrave MacMillan.

${ }^{17}$ Banet Sarah and Weiser: "Postfeminisme and Popular Feminism", Feminist Media Histories, Vol. 4,n' 2 (2018), pp. 152-166. See Banet-Weiser Sarah, Gill Rosalind and Rottenberg Chaterine: "Postfeminism, popular feminism and neoliberal feminism? Sarah Banet-Weiser, Rosalind Gill and Chaterine Rottenberg in Conversation", Feminist Theory, Vol. 21, no 1 (2020), pp. 3-24. See also Suwastini, Ni Komang Arie: "Perkembangan Feminisme Barat dari Abad ke Delapan Belas hingga Postfeminisme: Sebuah TInjauan Teoritis", Jurnal Ilmu Sosial dan Humaniora, Vol. 2, no 1 (2013), pp. 198-208.

${ }^{18}$ Kriyantono, Rachmat and Bernard McKenna: "Developing a Culturally-Relevant Public Relations Theory for Indonesia", Malaysian Journal of Communication, Vol. 33, $\mathrm{n}^{\circ} 1$ (2017), pp. 1-16. See also Aggestam, Karin, and Annika Bergman-Rosamond: "Swedish Feminist Foreign Policy in the Making: Ethics, Politics, and Gender." Ethics \& International Affairs Journal, Vol. 30, nº 3 (Fall 2016) pp. 323-334.
} 


\section{Methodology}

This study aims to provide information on women participation in international art performance, able to transfer their knowledge through their activities, to maintain their traditional art forms such as classical, contemporary, Nusantara dance and modern dance. This study is more descriptive than interpretive as it focuses on a rich description of the phenomenon under study. The ten participants in this study were recruited from founder and members of Semarak Candrakirana Art Studio, committee, mask dancer from foreign countries, and people (domestic and foreign spectators). The location of this research is Kedasih Street No. 22, Kerten, Laweyan district, Surakarta regency. Corresponding to its slogan "The Spirit of Java", Surakarta is a strategic city in both trading and cultural areas. Its strategic location makes Surakarta crowded with sellers coming from outside town, making it the trading city center. Surakarta is one of Mataram Kingdom's heirs as indicated with the existence of Keraton Kasunanan (Kasunanan Palace) and Pura Mangkunegaran.

This research was conducted from January to August 2019. Most of the members of Semarak Candrakirana Art Center are women (135 out of 150). These ten participants were chosen as representatives of the different background. Researcher made interviews with founder and members of Semarak Candrakirana Art Studio, mask dancer and people. Other data were collected through observations and document analysis. Primary data were assembled through in depth interviews with the ten participants. Interviews lasted approximately 30 to 45 minutes and were conducted in both Javanese and Indonesian language. All interviews were audio-recorded and transcribed. The translation of the transcriptions were done by the first researcher and then verified by another competent bilingual researcher. All transcripts were sent back to the participants for verification of content and meanings. These interviews were conducted for a month. There has been follow up contact between the researcher and the participants through phone calls and text messaging (WhatsApp) since which contributed additional data. Direct observations were made by researchers to see traditional and modern dance exercises performed by members of the Art Center.

The documents used in this study include books or archive profiles of the studio along with photos of its international performances. The researcher firstly read the entire set of data, identifying all productive and reproductive tasks based on the activity profiles. The activity profile covers both traditional art within Semarak Candrakirana Art Center and intercultural relations. Then, the researcher make a list separating the women who have access to resources, those who control their use and those who control the benefits to the community. Furthermore, the researcher identifies the factors that influenced the differentiation made in the gender division in terms of access and control within the Semarak Candrakirana Art Center, as listed in the two profiles. Finally, the researcher is able to determine the different effects of social change on women.

\section{Discussion and Results}

The Semarak Candrakirana Art Center is a dance studio that has eight dance trainers. The dance trainers are graduates of the Indonesia Institute of the Arts (ISI) Surakarta. This dance studio offers dance exercises and performances for classical, contemporary, Nusantara dances and modern dances. From $31^{\text {th }}$ July 2008 until now, Semarak Candrakiranna art studio has various awards such as representatives of Indonesian dancers. Semarak Candrakirana art center has representd Indonesia in several times. In several international performances, Semarak Candrakirana has received awards from France (2008), the Netherlands (2009), and China (2010). Nusantara dance and modern dance several times participated in the international performance as the opening for SIPA. The range age of member Semarak Candrakirana are as follos: age 16-20 = 120 person, $21-25=$ seven person, $26-30=$ seven person and upper than 32 
is one person. In this research only ten women were interviewed as founder and members. There are three as college students (people), one as graduate from ISI, three as vocational school students, three as foreign mask dancers and three as high school students.

Three participants joined Semarak Candrakirana through friends. They are college school students who wanted to maintain traditional culture. Three college students stated that watching international performance (SIPA) is important for maintaining traditional culture and made them proud. Classical dance is indeed long and difficult to learn, but it shows its authority as a legacy of the royal period. Another reason for one student from ISI to join the Semarak Candrakirana art studio is to be able to perform in international performances like SIPA and IMF through Nusantara dance. In addition, three foreign masks dancers reported the desire to improve her self-confidence and competence within Semarak Candrakirana. The Art Center is a place where the women are able to gain dignity and equality with men. Female students who enter Semarak Candrakirana art studio can increase their potential and talent. In the Semarak Candrakirana art studio, women can get the same opportunities as men to support diplomacy, so there is gender equality.

A female vocation student said that joining the Semarak Candrakirana improved her life. She has danced in overseas international performances. Another vocation student also said that Semarak Candrakirana, as an Art Center, had cooperated with local and national governments. The improvement of the welfare of the women involved is quite relevant. Women who are members of the studio art can increase their income because they can perform in school or in community activities. Women of Semarak Candrakirana usually come to the studio after finishing their school activities or after side job hours. In addition, one of the senior high students had a different schedule because she is also a free-lance worker. She comes to Semarak Candrakirana at around 5 or 6 p.m. The members of Semarak Candrakira art center can choose one of the kinds of dancing, classical, contemporary, Nusantara dance and modern dance. The members participate in one of these dances only twice a week, on Tuesdays and Fridays during two hours from $5 \mathrm{pm}$. Unlike the other six participants, the college students only join the activities of this studio when Semarak Candrakirana prepares a performance. As a college student, she is always aware of the influence that her involvement in Semarak Candrakirana has on her classmate. She thinks it can be used as a way of introducing Semarak Candrakirana in the society. She also uses her social media to introduce this art studio. Another college student stated that as a member of this Nusantara dance, she can promote national identity through intercultural relationship. The Nusantara dance sometimes used to be mystical in nature with a ritual performance, deemed in contradiction to certain religious teachings. For this reason, it needed a better understanding by all members of Semarak Candrakirana because it is an art and it tries to promote the Indonesian culture.

The instructor and founder maintains relations with cultural groups from other countries. She said that good communication with these international cultural groups stemmed from his experience at ISI Surakarta. Furthermore, the government of Surakarta and the Indonesia Ministry of Education and Culture support and provide legal permission for this activity. Maintaining classical, contemporary, Nusantara and modern dance within Semarak Candrakirana needs support from their families, school and university since most members of Semarak Candrakirana have families. In an interview, a male member of Semarak Candrakirana stated that all parents of the women involved agree with their daugther involvement in Semarak Candrakirana, including their twice weekly evening practice sessions. Some parents accompany the troupe on their overseas tours. A male officer of the Department Education and Culture in Surakarta said that promoting the traditional culture of Surakarta requires public participation not only among the members of Semarak Candrakirana but also of citizens concerned with traditional culture who perceived it as the root of national identity. The attempt taken by women 
affiliated with Semarak Candrakirana Art Studio in organizing SIPA 2018-2019 is an important example to be presented, recalling that year as the year the soldiers of the radical group returned to their own states. Indonesia is so far known by international community as the state that has a significant number of its citizens affiliated with this radical group. Art staging becomes an alternative to Indonesians to improve their image and a bargaining position because culture has high values acceptable to people with different background. International level-culture through SIPA becomes a mean of showing to the public that safety and comfort are still protected by government. The international performance of Nusantara and modern dance contributes to the positive image of this regency and more indirectly to the popularity of Indonesia as a multicultural country.

The statements presented above highlight five main points with respect to the promotion of traditional culture: national identity, positive image, public participation, national interest, and diplomacy. These are important for a multicultural country such as Indonesia. First, culture is essential to national identity. Indonesia is one of the most diverse and multicultural countries in the world and has dynamic relations with other countries. Promoting culture is synonymous to promoting national identity. Second, promoting culture increase good communication or relations with other countries. Third, after many terrorist attacks, Indonesia needs to improve its image. Several countries see Indonesia as a place of terrorism. People believe that culture has an universal value. Culture can also be a tool of soft diplomacy. Fourth, promoting culture through international performance is an effort in soft diplomacy with the aim of improving the Indonesian's image and bolster national interests. Fifth, promoting culture is not the only program of the government. Non-goverment actors also have opportunities to support this program. Citizens too have the responsibility of supporting this government policy and one way to support the government policy is to maintain national identity by promoting it at the international level. In the nation's interest, goverment and non-goverment actors must cooperate in diplomatic ventures.

\subsection{The Role of Semarak Candrakirana Members as Agent of Citizen Diplomacy}

As aforementioned, citizens are not only subjets of a state, citizens of one state interact with the citizens of other states and thus, citizen's diplomacy is also beneficial for the states because they help to achieve some national interests. From this angle, the government has the responsibility to promote citizen diplomacy. Today women have the opportunity to appear as agents in international relations through citizen diplomacy. It is more than a social symbol inherent in the figure of women, it is a praiseworthy new status avhieved by women at international level. ${ }^{19}$

Therefore, citizen diplomacy can become an important factor in the creation of a new social order and a peaceful society. ${ }^{20}$ The attempt to promote peace through diplomacy is in line with the Javanese people's philosophy, called life harmony. As aforementioned, citizen diplomacy can be considered the second-line in the diplomacy, an informal and unofficial diplomatic attempt to create positive relations between states by building trust among its citizens. For that reason, a solid foundation is needed to establish a harmonious relation between two or many states through citizens' involvement. Surakarta women, as part of the society, having gotten empowerment through education and opportunities provided by the local government, are highly motivated to participate in the implementation of citizen diplomacy.

\footnotetext{
${ }^{19}$ Mori, Jennifer: "How Women Make Diplomacy: The British Embassy in Paris 1815-1841", Journal of Women's History, Volume 27, no 4 (Winter 2015), pp. 137-159.

${ }^{20}$ Ogbonnaya, Offor, E. et al: “A Critical Reflection On The Theory And Practice Of Citizen Diplomacy In Nigeria's Foreign Policy And External Relations”, South East Journal of Political Science, Vol. 4, nº1 (2018)., pp. 60.
} 
The activities of citizen diplomacy have often coincidentally started when artists communicate and establish solid relationships abroad. Incidentally, the dance art coach of the Semarak Candrakirana is a graduate of an art school that was once sent to perform abroad. Citizens diplomacy that promotes cultural interrelations through sustainable people-to-people communications usually involves "scholars, senior journalists, former government officials, and former military officers" but can also simply include people communicating with people in productive ways that ensure and further develop understanding and mutual respect. Track-II diplomacy provides participants with settings and conditions that are essential to achieve effective dialogue, and are rooted in engagement and relationship building targeted at cultivating trust and mutual understanding between peoples. Furthermore, track-II diplomacy (unofficial state diplomacy) initiatives are related to promoting national identity, reducing tensions or facilitating the resolution of a conflict, but differ in their nature, context, and leaders.

Citizens diplomacy as track-II diplomacy usually takes place in informal settings in a manner which does no involve government officials (at least not from its inception). Moreover, citizens diplomacy does not require the parallel conduct of official and formal negotiations by the government (Track-I diplomacy), and can be held independently and separately from any official negotiations. Additionally, Track-II diplomacy can be "hard" or "soft". While "hard" Track-II diplomacy is aimed at negotiating an agreement between the parties involved, "soft" Track-II diplomacy is aimed at "dialogue, familiarization, exchange of information, assessments, and security concerns". ${ }^{21}$ To avoid the asymmetric cooperation, a lot of information, multilateral dialogue needs to be done to develop a the definition of cooperation accepted, which meets the needs of the co-partner countries.. ${ }^{22}$ Thus, Track-II diplomacy aims at creating a positive relationship between both sides involved for which the fundamental requisite is the establishment of trust between citizens of other countries. Thus, in order to build a solid foundation of harmonious relations between two or more countries, to build a new social order, civil society must be involved in this process.

Harmonious relations between citizens through intercultural relations is important. Semarak Candrakirana Art Center as a cultural group established good relations with other citizens through art performance. Since 2005 this studio has held international performances in SIPA and Semarak Candrakirana Art Center has become an agent of citizens diplomacy. The role of the members of Semarak Candrakirana as citizen diplomats according to Odoh, is related to their activities representing sectoral, regional, or local economic interests. ${ }^{23}$ Citizens (business, cultural groups, scholars, etc) who become diplomats are sub-state actors. They communicate and influence relations between non-state actors to achieve their specific interests. Promoting traditional culture from central Java can help to increase understandings and improve international relations, for example, between Indonesia and South Korea, Italy, Spain and Hungary. These four countries send annually their citizens to participate in SIPA.

Promoting traditional culture from Surakarta has had a positive impact. First, promoting traditional dance through international performance (SIPA) is a positive activity in maintaining and strengthening national identity. Every year the women who are members of the Semarak Candrakirana show their ability to dance in an international show held in Surakarta regency. This activity can increase the confidence of Surakarta women to appear in prestigious international events. Second, though citizens diplomacy has varied interpretations among

\footnotetext{
${ }^{21}$ Vanc, Antoaneta M, Kathy R. Fitzpatric: "Scope and Status of Public Diplomacy Research by Public Relations Scholars, 1990-2014”, Public Relations Review, Vol. 42, n 3 (September 2016), pp. 432-440.

${ }^{22}$ Anamika Barua: "Water Diplomacy as an approach to regional cooperation in South Asia: A case from the Brahmaputra Basin”, Journal of Hydrology, Vol.567, (2018), pp. 30-40.

${ }^{23}$ Odoh, S.I. et al: "Reflections on the Theory and Practice of Citizen Diplomacy in the Conduct od Nigeria's, Foreign Policy, op. cit., pp. 9.
} 
scholars, it implies the transnational flow of information and ideas through the interaction of private groups and interests of different countries which influence the formation and execution of foreign policies in the pursuit of national interests. Taking into consideration the increasing number of foreign tourists, this Art Center can be an agent to promote an iconic element of Indonesian culture at the international level and thus expanding the national interest. Third, as citizens of Surakarta, women from Semarak Candrakirana Art Center maintain traditional dances as a part of Indonesia culture and they participate in building society. When tourists come to Surakarta and watch the performance of Semarak Candrakirana, the tourist dollars benefit the local community. Foreign people who watch dance performances by Semarak Candrakirana members are encouraged by the committee to buy local products. Local products sold by the community include food, handicrafts, clothing and accessories. This aims to increase the popularity of local products while increasing the welfare of the community. Fourth, members of Semarak Candrakirana Art Center became agents of citizens diplomacy. The women's activity through their international performance supports government diplomacy. The women's participation implies that culture can be a tool of soft diplomacy, helping to establish and develop good relationships with citizens from other countries and reducing tension between countries.

\section{Conclusion}

In democratic nations like Indonesia, women have the opportunity to contribute to the building of society. In this example, their participation is conducted through intercultural relations. Intercultural relations are tools that promote and advance national interests, such as the attainment of foreign investments to increase societal welfare. It is important to create and maintain a positive image of Indonesia. The women of Semarak Candrakirana Art Center of Kedasih Street No.22, Kerten, Laweyan district, Surakarta regency maintain the classical, contemporary, Nusantara dance and modern dance, going beyond the limits of Surakarta and reaching international levels (SIPA international art performance). Therefore Semarak Candrakirana Art Center becomes an agent of citizen diplomacy through the promotion of Indonesian culture internationally. This activity supports government diplomacy. It implies that this activity have been done to influence citizens and governments of SIPA. It also means that women's participation through international performance can enhance the positive image of Indonesia abroad. As agents of citizens diplomacy, the women of Semarak Candrakirana establised and pursue good relationships between Indonesia and other countries participating in SIPA. Semarak Candrakirana tries to create good relationships with many countries improving the positive image of Indonesia.

\section{Bibliography}

Aggestam, Karin, and Annika Bergman-Rosamond: "Swedish Feminist Foreign Policy in the Making: Ethics, Politics, and Gender", Ethics \& International Affairs Journal, Vol. 30, n 3 (Fall 2016), pp. 323-334.

Anamika Barua: "Water Diplomacy as an approach to regional cooperation in South Asia: A case from the Brahmaputra Basin”, Journal of Hydrology, Vol. 567 (2018), pp. 30-40.

Asante, Kwadwo Adusei, et al: “Gender Mainstreaming and Women's Roles in Development Projects: A Research Case Study from Ghana, Feminism", Social Science and Knowledge Advances in Gender Research, Vol. 20 (August 2015), pp. 177-198. 
Asmarani, Ratna: Perempuan Dalam Perspektif Kebudayaan, Sabda Vol. 12, nº 1 (2017), pp 716.

Banet Sarah and Weiser, Postfeminism and Popular Feminism, Feminist Media Histories, Vol. 4, no 2 (2018), pp. 152-166.

Banet-Weiser Sarah, Gill Rosalind and Rottenberg Chaterine: "Postfeminism, popular feminism and neoliberal feminism? Sarah Banet-Weiser, Rosalind Gill and Chaterine Rottenberg in Conversation”, Feminist Theory, Vol. 21, no 1 (2020), pp. 3-24.

Costigliola, Frank: "Pamela Churchill, Wartime London, and the Making of the Special Relationship.” Diplomatic History, Vol 36, no 4 (September 2012), pp. 753-762

Dean, Robert: "The Personal and the Political: Gender and Sexuality in Diplomatic History." Diplomatic History, Vol. 36, no 4 (September 2012) pp. 793-767.

Fulda, Andreas: "The Emergence of Citizen Diplomacy in European Union- China Relations: Principles, Pillars, Pioneers, Paradoxes", Diplomacy \& Statecraft, Vol. 30, n 1 (2019), pp. 188-216.

Gill, Rosalind and Christina Scharff. (2011): New Femininities: Post feminism, Neoliberalism and Subjectivity, Hampshire and New York: Palgrave MacMillan.

Hadiz VR and Chryssogelos A: Populism in world politics: A comparative cross-regional perspective. International Political Science Review Vol. 38, nº 4 (2017), pp. 399-411.

Huijgh, Ellen: "Changing Tunes for Public Diplomacy: Exploring the Domestic Dimension". Exchange: The Journal of Public Diplomacy, Vol. 2. $\mathrm{n}^{\mathrm{o}}$ 1, (2013), pp. 62-73.

Jewkes, Rachel, et al: "Hegemonic Masculinity: Combining Theory and Practice in Gender Interventions", Culture, Health \& Sexuality Journal, Vol. 17, nº S2 (2015), pp. 112-127.

Jovita, H. D., Nashir, H., Mutiarin, D., Moner, Y., \& Nurmandi, A. Social capital and disasters: How does social capital shape post-disaster conditions in the Philippines? Journal of Human Behavior in the Social Environment, Vol. 29, no 4 (2019), pp. 519-534.

Kumar, Anup \& Holli A. Semetko: "Peace Communication in Cross-border MediaFlows", Journal of Communication, Vol. 68, n 3 (June 2018), pp. 612-635.

Lips B. Mirriam A. Reconstructing, Attributing and Fixating Citizen Identities in Digital-era Government, Media, Culture \& Society, Vol. 35, nº 1 (January 2013), pp. 61-70.

Melissan Jan and Matthew Caesar-Gordon. "Digital diplomacy" and the securing of Nationals in a Citizen-Centric World, Global Affairs, Vol. 2, n 3 (October 2016), European International Studies Association, pp. 1-10.

Mori, Jennifer, How Women Make Diplomacy: The British Embassy in Paris 1815-1841, Journal of Women's History, Volume 27, nº 4 (2015), pp. 137-159.

Odoh, S.I. etal: "Reflections on the Theory and Practice of Citizen Diplomacy in the Conduct of Nigeria's Foreign Policy", Journal Of Humanities And Social Science, Vol. 19, n 10, Ver. VIII, (2014), pp. 09-14.

Ogbonnaya, Offor, E. et.al: "A Critical Reflection On The Theory And Practice Of Citizen Diplomacy In Nigeria's Foreign Policy And External Relations", South East Journal of Political Science, Vol. 4, nº1 (2018), pp. 56-67.

Scoth Gilles \& Smith: "Introduction: Private Diplomacy, Making the Citizen Visible", New Global Studies, Vol.8, no 1 (March 2014), pp. 1-7. 
PBB: 30 ribu Militan ISIS Tinggalkan Irak dan Suriah, 14 Agustus 2018 Tempo.co.id

Towns, Ann, and Birgitta Niklasson. "Gender, International Status, and Ambassador Appointments." Foreign Policy Analysis 13 (2017): 521-540.

Ujara, Ese: "Citizen Diplomacy and Nigeria's International Image: The Social Constructivist Explanation", Covenant Journal of Business and Social Sciences, Vol. 6, n ${ }^{\circ} 2$ (December 2014), pp. 14-30.

Suwastini, Ni Komang Arie, Perkembangan Feminisme Barat dari Abad ke Delapan Belas hingga Postfeminisme: Sebuah TInjauan Teoritis, Jurnal Ilmu Sosial dan Humaniora, Vol. 2 n $^{\circ}$ 1 (2013), pp. 198-208.

Vanc, Antoaneta M, Kathy R. Fitzpatric: "Scope and Status of Public Diplomacy Research by Public Relations Scholars, 1990-2014”, Public Relations Review, Vol. 42, no 3 (September 2016), pp. 432-440. 